\title{
Spatial and Temporal Variability of Nitrous Oxide Emissions from a Large Subtropical Reservoir in Eastern China
}

\author{
Le Yang*, Hepeng Li, Jun Wang \\ Zhejiang Academy of Forestry, Hangzhou, Zhejiang Province
}

Received: 12 June 2018

Accepted: 17 May 2018

\begin{abstract}
Carbonaceous greenhouse gases (i.e., $\mathrm{CO}_{2}, \mathrm{CH}_{4}$ ) have often reported to be emitted from the surfaces of reservoirs, while other non-carbonaceous greenhouse gases are not available to many reservoirs. In this study, the spatiotemporal variability of $\mathrm{N}_{2} \mathrm{O}$ emissions from Xin'anjiang Reservoir was investigated at the different regions over a 13-month period using the method of the static floating chambers combined with gas chromatography. Results showed that the average $\mathrm{N}_{2} \mathrm{O}$ emission flux was the highest in the downstream river $\left(220.24 \pm 153.68 \mu \mathrm{g} \mathrm{m}^{-2} \cdot \mathrm{s}^{-1}\right)$, followed by the upstream river $\left(49.85 \pm 48.55 \mu \mathrm{g} \mathrm{m}^{-2} \cdot \mathrm{s}^{-1}\right)$. The reservoir's main body had the lowest flux $\left(26.61-39.07 \mu \mathrm{g} \mathrm{m}^{-2} \cdot \mathrm{s}^{-1}\right)$. Seasonal variability indicated that the average $\mathrm{N}_{2} \mathrm{O}$ emission fluxes before the dam reached their maximum in March, which was likely influenced by the disappearance of thermal stratification then, caused a short $\mathrm{N}_{2} \mathrm{O}$ flux peak at the waterair interface. A thorough investigation should be carried out at the different reservoir regions for a longterm basis to discover the spatiotemporal variability in $\mathrm{N}_{2} \mathrm{O}$ emission flux in a hydroelectric reservoir system, which could avoid the error of estimating the $\mathrm{N}_{2} \mathrm{O}$ emissions incorrectly.
\end{abstract}

Keywords: $\mathrm{N}_{2} \mathrm{O}$ emission, $\mathrm{N}_{2} \mathrm{O}$ flux, spatiotemporal variability, Xin'anjiang Reservoir

\section{Introduction}

Nitrous oxide $\left(\mathrm{N}_{2} \mathrm{O}\right)$, a trace gas that contributes to stratospheric ozone destruction and atmospheric warming, has a radiative forcing of $+0.17 \mathrm{~W} / \mathrm{m}^{2}$ nowadays [1], and its atmospheric concentration has increased from $270 \mathrm{ppbv}$ in the pre-industrial era to $328 \mathrm{ppbv}$ in 2016 [2]. Among the greenhouse gases covered by the Kyoto Protocol, $\mathrm{N}_{2} \mathrm{O}$ is the third largest contributor to global warming after carbon dioxide

*e-mail: yangboshi@live.cn
$\left(\mathrm{CO}_{2}\right)$ and methane $\left(\mathrm{CH}_{4}\right)$, which is responsible for $7 \%$ of anthropogenic global warming and has a global warming potential about 298 times that of $\mathrm{CO}_{2}$ and a long residence time ( $\sim 114$ years) in the atmosphere [3].

Wetlands and watercourses are important $\mathrm{N}_{2} \mathrm{O}$ sources, e.g., it has been estimated that 106, 93-111, and $974 \mathrm{Gg} \mathrm{N} \mathrm{N}_{2} \mathrm{O} / \mathrm{yr}$ were emitted from reservoirs, rivers, and coastal zones, respectively [4-6]. Reservoirs, as a kind of inland water, are different from streams, rivers and lakes, because the river impoundment significantly changes the water environment, especially in terms of nutrient status and physicochemical conditions, which has an impact on the spatiotemporal variability of $\mathrm{N}_{2} \mathrm{O}$ emission [7]. The spatiotemporal variability of $\mathrm{N}_{2} \mathrm{O}$ 
emission was reported from several hydroelectricity reservoirs in China, but the patterns were distinct in the different reservoirs, e.g., $\mathrm{N}_{2} \mathrm{O}$ fluxes in Wujiangdu, Hongjiadu, and Dongfeng reservoirs reached their maximum in November, September, and April, respectively $[7,8]$, while the peak value of $\mathrm{N}_{2} \mathrm{O}$ emission from Three Gorges Reservoir occurred in June and July $[9,10]$, which indicated that $\mathrm{N}_{2} \mathrm{O}$ emissions from different reservoirs differed widely both among systems and through time [11].

The effects of thermal stratification, $\mathrm{N}$ and $\mathrm{O}_{2}$ availability on $\mathrm{N}_{2} \mathrm{O}$ production were complicated by nitrification and denitrification in the water column [11]. A high $\mathrm{N}$ load into reservoirs, including ammonia $\left(\mathrm{NH}_{4}^{+}\right)$, nitrite $\left(\mathrm{NO}_{2}^{-}\right)$, and nitrate $\left(\mathrm{NO}_{3}^{-}\right)$could increase the substrates for nitrification and denitrification, thus there were the positive correlations between $\mathrm{N}_{2} \mathrm{O}$ concentrations and nitrogen content (i.e., $\mathrm{NH}_{4}^{+}, \mathrm{NO}_{3}^{-}$, $\mathrm{TN})$ in reservoirs and rivers in China $[7,8,12]$. Besides nutrient status, water temperature and dissolved oxygen (DO) also influenced $\mathrm{N}_{2} \mathrm{O}$ formation. Similar to natural lakes, thermal stratification often existed in those large and deep reservoirs, and the seasonal alternation between thermal stratification and destratification could promote the exchange of energy, dissolved gas, and other substances between epilimnion and hypolimnion in the water column [13]. Furthermore, DO would stratify due to the response to thermal structure in reservoirs by the regulation of chromophoric dissolved organic matter [14], and DO concentration was crucial for $\mathrm{N}_{2} \mathrm{O}$ production and has a negative relationship with $\mathrm{N}_{2} \mathrm{O}$ emission from reservoirs and rivers [7, 12]. Thus, the seasonal variability of $\mathrm{N}_{2} \mathrm{O}$ emissions were probably determined by the nutrient status and thermal structure of a reservoir.

Xin'anjiang Reservoir is the largest reservoir in eastern China, with a water area of $478 \mathrm{~km}^{2}$ and a mean water depth of $34 \mathrm{~m}$, and is a mesotrophic lake at present. Although $\mathrm{CO}_{2}$ emission from Xin'anjiang reservoir was reported before [15], $\mathrm{N}_{2} \mathrm{O}$ emission was unknown. In this paper, we measured the $\mathrm{N}_{2} \mathrm{O}$ emission from 5 different regions to investigate the spatiotemporal variability patterns of $\mathrm{N}_{2} \mathrm{O}$ emission from Xin'anjiang Reservoir from December 2014 to December 2015. The study aims to (1) compare the $\mathrm{N}_{2} \mathrm{O}$ emission from the different regions (riverine zone versus lacustrine zone) and (2) study the seasonal variability of $\mathrm{N}_{2} \mathrm{O}$ emission.

\section{Experimental Procedures}

\section{Study Area}

Xin'anjiang Reservoir $\left(29^{\circ} 28^{\prime}-29^{\circ} 58^{\prime} \mathrm{N}, \quad 118^{\circ} 42^{\prime}-\right.$ $\left.118^{\circ} 59^{\prime} \mathrm{E}\right)$ is also called Thousand-island Lake, because 1,078 islands are distributed in the reservoir. Xin'anjiang Reservoir has a basin area of $10,480 \mathrm{~km}^{2}$ when the normal water storage water level is $108 \mathrm{~m}$. The storage water in Xin'anjiang Reservoir derives from 33 different tributaries, but Xin'anjiang River, i.e., the watercourse of northwest (NW) lake, is the most dominant upstream inflow river, which occupies $60-70 \%$ of total surface runoff of the reservoir [16]. In addition, the reservoir's main body consists of northeast (NE) lake, southwest (SW) lake, southeast (SE) lake, and central lake.

Xin'anjiang Dam, located in Tongguan Gorge, was the first immense hydropower station which was designed, equipped, and constructed all by Chinese after the foundation of the People's Republic of China in 1949. Xin'anjiang Dam began to be built in 1957 and water storage started in 1959. The height and length of the dam was $105 \mathrm{~m}$ and $462 \mathrm{~m}$, respectively. At maximal operating level the reservoir volume is 17.8 billion $\mathrm{m}^{3}$, and the annual mean discharge of Xin'anjiang River is $357 \mathrm{~m}^{3} \cdot \mathrm{s}^{-1}$. The average turnover time of the impounded water is estimated to be $\sim 2$ years [17].

Xin'anjiang Reservoir is located in the north edge of a subtropical zone with humid monsoonal climatic condition, with the annual mean temperature of $17.7^{\circ} \mathrm{C}$, annual accumulated precipitation of $2015.1 \mathrm{~mm}$, and evaporation of $712.9 \mathrm{~mm}$ in 2015 . Water level fluctuated between $98.5 \mathrm{~m}$ to $104.5 \mathrm{~m}$ in Xin'anjiang Reservoir. Four seasons are easily divided throughout the year in the reservoir, i.e., spring (March to May), summer (June to August), autumn (September to November), and winter (December to February). Xin'anjiang Reservoir is warm monomictic, with a long period of thermal stratification [13].

The sampling campaign was conducted in the 5 transects of the upstream river, the reservoir's main body and the downstream river (Fig. 1). The NW

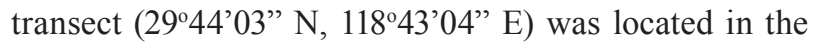
main inflow inlet of Xin'anjiang Reservoir, and had a watercourse width of $0.3 \mathrm{~km}$. 3 sampling points were chosen from the margin to pelagic zones in the NW

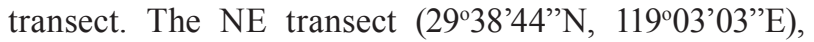

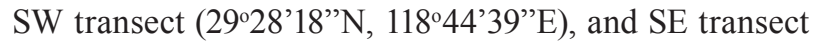
(2928'39'N, $118^{\circ} 45^{\prime} 20^{\prime}$ 'E) were located in open water areas of NE lake, SW lake, and SE lake, respectively. 5 sampling points were chosen from the margin to pelagic zones in the NE, SW, and SE transects, respectively. In addition, 4 sampling points were selected in the downstream river below the dam, with a distance of $0.35 \mathrm{~km}, 1 \mathrm{~km}, 4 \mathrm{~km}$, and $7 \mathrm{~km}$ away from Xin'anjiang Dam, respectively.

\section{Sampling Strategy}

Monthly measurement was conducted for each sampling site, which was controlled from 8:30 a.m. to 11:30 a.m. Sampling campaigns were carried out at the end of each month and would last for a week; a small boat was used to transport between different sampling points in each transect and sampling was done in the same boat.

The gas samples were collected by the static chambers, and 3 chambers were deployed simultaneously. The floating static chamber $(65 \mathrm{~cm}$ in 


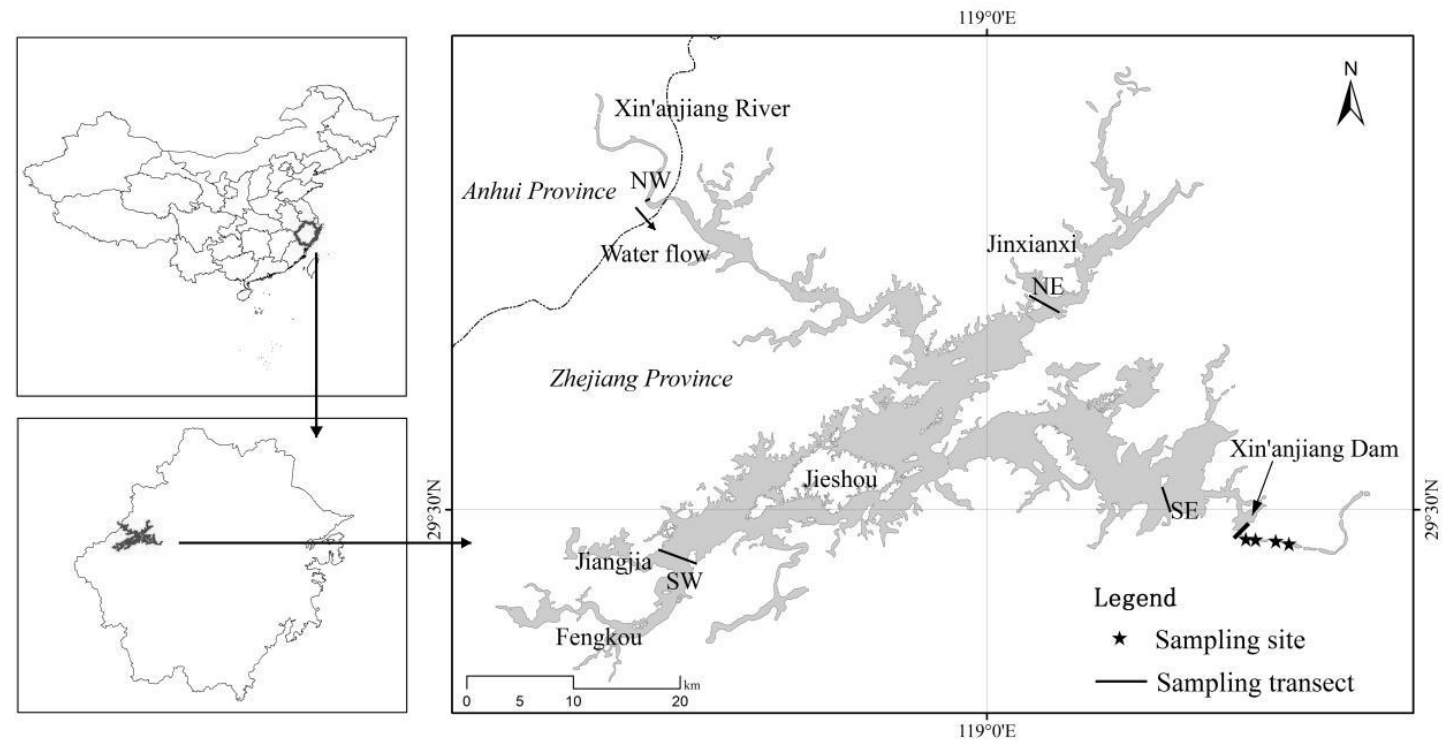

Fig. 1. Distribution map of the sampling transects and sampling sites in Xin'anjiang Reservoir.

length $\times 45 \mathrm{~cm}$ in width $\times 40 \mathrm{~cm}$ in height) consisted of a plastic box without a cover that was wrapped in light-reflecting and heatproof materials to prevent temperature variation inside the chambers; in addition, plastic foam collars were fixed onto opposite sides of the chamber. The headspace height inside the chamber was about $35 \mathrm{~cm}$. A silicone tube $(0.6 \mathrm{~cm}$ and $0.4 \mathrm{~cm}$ outer and inner diameters, respectively) was inserted into the upper central side of the chamber to collect gas samples, and the gas samples were dried with plexiglass tubes filled with calcium chloride anhydrous (analytical reagent), which could remove the moisture in the gas samples and prevent the biological reactions. Another silicone tube was inserted into the upper corner side of the chamber to keep the air pressure balanced between the inside and the outside of the chamber. The gases in the headspace of the chamber were collected into airsampling bags $(0.5 \mathrm{~L}$; Hedetech, Dalian, China) four times every $7 \mathrm{~min}$ over a 21 -min period using a handdriven pump (NMP830KNDC; KNF Group, Freiburg, German).

\section{Measurement Techniques and Flux Calculation}

The $\mathrm{N}_{2} \mathrm{O}$ concentrations in the air-sampling bags were analyzed using a gas chromatograph (Agilent 7890A; Agilent Technologies, Santa Clara, USA) with a electron capture detector (ECD) and separated with a Teflon column $(3 \mathrm{~m} \times 3 \mathrm{~mm})$ packed with Porpak-Q column (80-100 mesh). The oven, injector, and detector temperatures were at $70^{\circ} \mathrm{C}, 25^{\circ} \mathrm{C}$, and $330^{\circ} \mathrm{C}$, respectively. The flow rate of the carrier gas (pure $\mathrm{N}_{2}$ ) was $25 \mathrm{ml} / \mathrm{min}$. Standard mixed gas $\left(\mathrm{N}_{2} \mathrm{O}\right.$ : 0.308 ppm; provided by China National Research Center for Certified Reference Materials, Beijing) was used to quantify the $\mathrm{N}_{2} \mathrm{O}$ concentration in one of every
10 samples, which kept the coefficient of variation of the $\mathrm{N}_{2} \mathrm{O}$ concentration in the replicated samples below $1.5 \%$.

The increasing rate of the gas concentration $(\mathrm{d} c / \mathrm{d} t)$ within the static chamber was calculated as the slope of the linear regression of the gas concentration versus time. It was suggested that the nonlinear relationship between gas flux and time would be better to determine the steeper initial slope in the chambers [18]. Thus, the para-curve model was made preferential to the linear one. Otherwise, the linear model was accepted. Acceptance of the results was based upon two criteria: (1) the difference of $\mathrm{N}_{2} \mathrm{O}$ concentration between the initial gas sample and ambient air must be within $10 \%$ and (2) the correlation coefficient $\left(\mathrm{R}^{2}\right)$ had to be $>0.90$.

$$
F=\rho \times \frac{d c}{d t} \times \frac{273.15}{273.15+T} \times H
$$

...where $\mathrm{F}$ is the diffusive $\mathrm{N}_{2} \mathrm{O}$ flux $\left(\mu \mathrm{g} \mathrm{m}^{-2} \cdot \mathrm{s}^{-1}\right) ; \rho$ is density of gas under standard conditions $\left(1.962 \mathrm{~kg} \cdot \mathrm{m}^{-3}\right.$ for $\mathrm{N}_{2} \mathrm{O}$ ); $\mathrm{H}$ is height of the top of the inverted chamber to the water surface $(0.35 \mathrm{~m}$ here); 273.15 is absolute temperature at $0^{\circ} \mathrm{C}$; and $\mathrm{T}$ is air temperate $\left({ }^{\circ} \mathrm{C}\right)$.

\section{Statistical Analysis}

$\mathrm{N}_{2} \mathrm{O}$ fluxes were first tested by the KolmogorovSmirnov test to judge whether these data satisfied the normal distribution. If not, these $\mathrm{N}_{2} \mathrm{O}$ flux data would be transferred by elementary functions to satisfy the normal distribution. One-way analysis of variance (ANOVA) combined with the Tukey HSD test was used to analyze the differences in the average $\mathrm{NO}_{2}$ flux among the different transects. The data were analyzed using the SPSS (statistical product and service solution) 18.0 statistical package. 


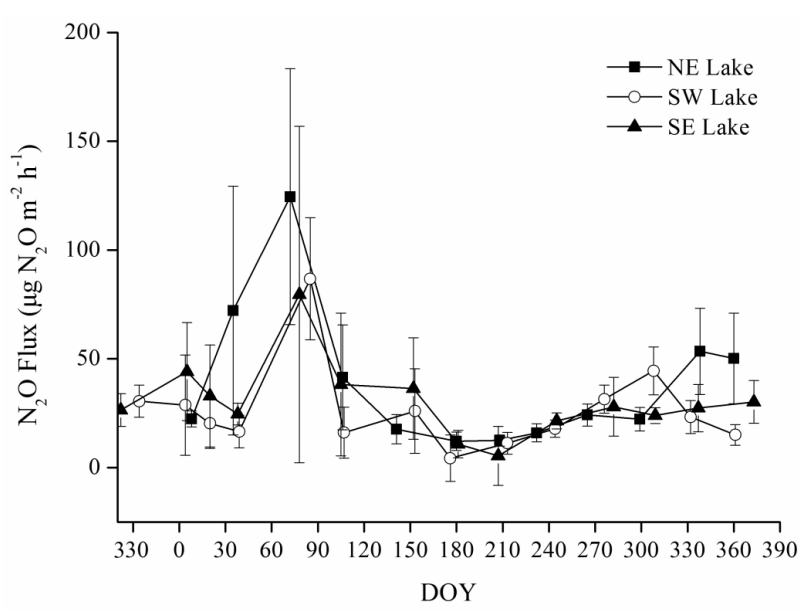

Fig. 2. Dynamics of average $\mathrm{N}_{2} \mathrm{O}$ emission from the main body of Xin'anjiang Reservoir.

\section{Results}

Seasonal Variability of $\mathrm{N}_{2} \mathrm{O}$ Emission from Xin'angjiang Reservoir

\section{$\mathrm{N}_{2} \mathrm{O}$ Emission from the Lacustrine Zone of Xin'angjiang Reservoir}

The average $\mathrm{N}_{2} \mathrm{O}$ emission flux in the $\mathrm{NE}$ transect climbed sharply from January $\left(22.40 \pm 3.68 \mu \mathrm{g} \mathrm{m}^{-2} \cdot \mathrm{s}^{-1}\right)$ to the maximum value in March $\left(124.52 \pm 58.84 \mu \mathrm{g} \mathrm{m}^{-2} \cdot \mathrm{s}^{-1}\right)$, dropped to the minimum in June $\left(12.12 \pm 4.24 \mu \mathrm{g} \mathrm{m}^{-2} \cdot \mathrm{s}^{-1}\right)$, and kept a low emission level until a minor increase in November $\left(54.69 \pm 24.91 \mu \mathrm{g} \mathrm{m} \mathrm{m}^{-2} \cdot \mathrm{s}^{-1}\right.$, Fig. 2). The average $\mathrm{N}_{2} \mathrm{O}$ emission flux in the $\mathrm{SW}$ transect firstly experienced a minor decrease from December $2014 \quad\left(30.53 \pm 7.43 \mu \mathrm{g} \mathrm{m}^{-2} \cdot \mathrm{s}^{-1}\right)$ to February $2015\left(16.58 \pm 7.51 \mu \mathrm{g} \mathrm{m}^{-2} \cdot \mathrm{s}^{-1}\right)$, witnessed a short pulse in March $\left(86.78 \pm 28.05 \mu \mathrm{g} \mathrm{m} \mathrm{m}^{-2} \cdot \mathrm{s}^{-1}\right)$, but declined immediately in April $\left(16.10 \pm 17.12 \mu \mathrm{g} \mathrm{m}^{-2} \cdot \mathrm{s}^{-1}\right)$, climbed slowly from June $\left(4.33 \pm 10.69 \mu \mathrm{g} \mathrm{m}^{-2} \mathrm{~s}^{-1}\right)$ to November $\left(44.45 \pm 10.95 \mu \mathrm{g} \mathrm{m}^{-2} \cdot \mathrm{s}^{-1}\right)$, and finally dropped again in the remaining time (Fig. 2). The average $\mathrm{N}_{2} \mathrm{O}$ emission flux in the SE transect started from December 2014 $\left(26.47 \pm 7.46 \mu \mathrm{g} \mathrm{m}^{-2} \cdot \mathrm{s}^{-1}\right)$, fluctuated slightly until February 2015, increased suddenly to the maximum in March $\left(79.56 \pm 77.35 \mu \mathrm{g} \mathrm{m}^{-2} \cdot \mathrm{s}^{-1}\right)$, then decreased slowly from April to July $\left(5.39 \pm 13.55 \mu \mathrm{g} \mathrm{m}^{-2} \cdot \mathrm{s}^{-1}\right)$, climbed gently in the remaining time and finally returned to the original level (Fig. 2).

\section{$\mathrm{N}_{2} \mathrm{O}$ Emission from the Riverine Zone of Xin'angjiang Reservoir}

The riverine zone of Xin'angjiang Reservoir could be divided into 2 parts, i.e., the upstream river and the downstream river. The average of $\mathrm{N}_{2} \mathrm{O}$ flux in the upstream river kept a relative low emission level between $20 \mu \mathrm{g} \mathrm{m}^{-2} \cdot \mathrm{s}^{-1}$ to $50 \mu \mathrm{g} \mathrm{m} \mathrm{m}^{-2} \cdot \mathrm{s}^{-1}$, except

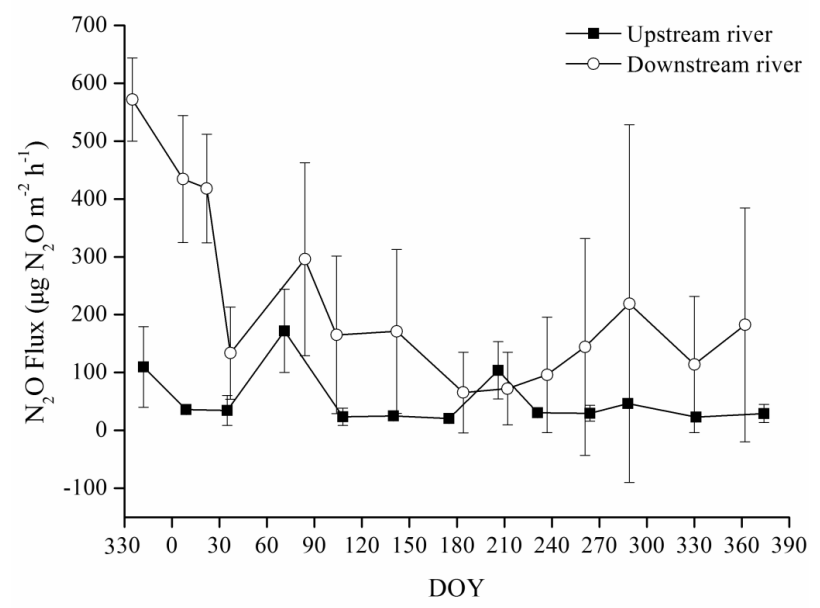

Fig. 3. Dynamics of average $\mathrm{N}_{2} \mathrm{O}$ emission from the riverine zone of Xin'anjiang Reservoir.

for December in $2014 \quad\left(109.67 \pm 69.66 \mu \mathrm{g} \mathrm{m} \mathrm{m}^{-2} \cdot \mathrm{s}^{-1}\right)$, March $\left(172.00 \pm 72.11 \quad \mu \mathrm{g} \quad \mathrm{m}^{-2} \cdot \mathrm{s}^{-1}\right)$ and July $\left(103.81 \pm 49.59 \mu \mathrm{g} \mathrm{m}^{-2} \cdot \mathrm{s}^{-1}\right)$ in 2015 (Fig. 3). The average $\mathrm{N}_{2} \mathrm{O}$ emission flux in the downstream river decreased from December $2014\left(571.59 \pm 71.90 \mu \mathrm{g} \mathrm{m}^{-2} \cdot \mathrm{s}^{-1}\right)$ to July $2015\left(65.43 \pm 69.69 \mu \mathrm{g} \mathrm{m}^{-2} \cdot \mathrm{s}^{-1}\right)$ with fluctuation between February to May 2015, increased slightly from July to October $\left(219.26 \pm 309.06 \mu \mathrm{g} \mathrm{m}^{-2} \cdot \mathrm{s}^{-1}\right)$, and fluctuated sightly in the last two months (Fig. 3).

\section{Spatial Variability of $\mathrm{N}_{2} \mathrm{O}$ Emission from Xin'angjiang Reservoir}

The average $\mathrm{N}_{2} \mathrm{O}$ emission flux in the downstream river $\left(220.24 \pm 153.68 \mu \mathrm{g} \mathrm{m}^{-2} \cdot \mathrm{s}^{-1}\right)$ was significantly higher than that in the lacustrine zone and the upstream river (Fig. 4), which was over 4 times higher than the upstream river $\left(49.85 \pm 48.55 \mu \mathrm{g} \mathrm{m}^{-2} \cdot \mathrm{s}^{-1}\right)$ and 5-8 times higher than the lacustrine zone $\left(26.61-39.01 \mu \mathrm{g} \mathrm{m}^{-2} \cdot \mathrm{s}^{-1}\right)$.

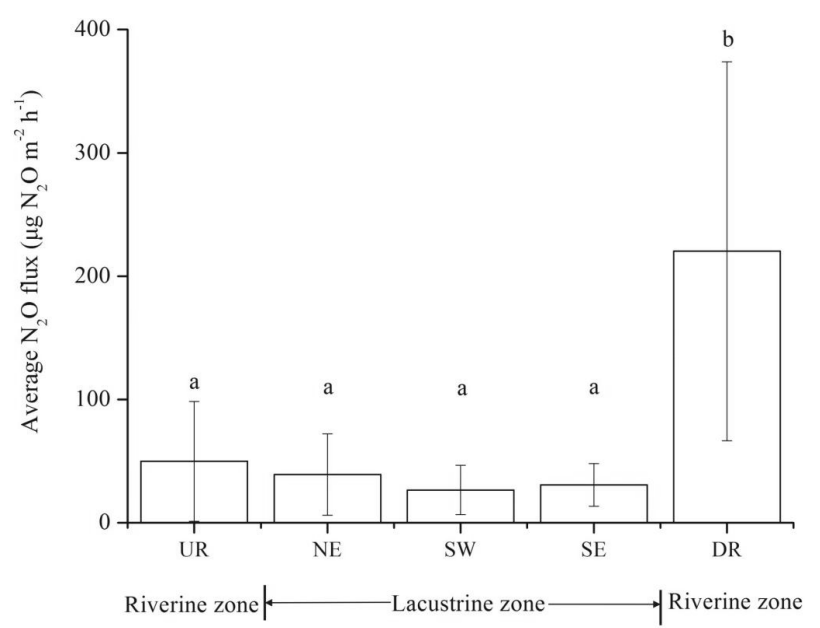

Fig. 4. Spatial variability of $\mathrm{N}_{2} \mathrm{O}$ emission from the different regions of Xin'angjiang Reservoir. 
Table $1 . \mathrm{N}_{2} \mathrm{O}$ emission from Xin'anjiang Reservoir compared with other reservoirs.

\begin{tabular}{|c|c|c|c|c|c|}
\hline & Country & Methods* $^{*}$ & Sampling periods & $\begin{array}{l}\mathrm{N}_{2} \mathrm{O} \text { fluxes } \\
\left(\mu \mathrm{g} \mathrm{m}^{-2} \cdot \mathrm{s}^{-1}\right)\end{array}$ & References \\
\hline \multicolumn{6}{|c|}{ Tropical Reservoirs } \\
\hline Petit Saut & $\begin{array}{l}\text { French } \\
\text { Guiana }\end{array}$ & FC & May and Dec., 2003 & $177.76 \pm 111.76$ & [19] \\
\hline Tucuru & Brazil & $\mathrm{FC}$ & Jun. Jul., 2000 & $233.33 \pm 170.83$ & [20] \\
\hline Samuel & Brazil & FC & Jun. Jul., 2000 & $400 \pm 270.83$ & {$[20]$} \\
\hline \multicolumn{6}{|c|}{ Subtropical Reservoirs } \\
\hline Three Gorges & China & FC & 2009-2011 & $14 \pm 21$ & [9] \\
\hline 5 reservoirs in Guizhou Province & China & TBL & Jul., 2007 to Jun., 2008 & $19.22(8.36-28.2)$ & {$[7,8]$} \\
\hline Xin'anjiang & China & $\mathrm{FC}$ & Dec., 2014 to Jan., 2016 & $34.84(27.91-50.11)$ & This study \\
\hline \multicolumn{6}{|c|}{ Temperate Reservoirs } \\
\hline Eguzon & France & TBL & 2011 & $32.45 \pm 31.35$ & {$[21]$} \\
\hline William Huasha & USA & TBL & May to Oct., 2012 & $78.75(-2200-4400)$ & {$[22]$} \\
\hline Eagle Creek & USA & TBL & $2005-2008$ & $83.75 \pm 307.92$ & {$[23]$} \\
\hline Yudushan & China & FC & May to Oct., 2009 & 16.51 & [24] \\
\hline \multicolumn{6}{|c|}{ Boreal Reservoirs } \\
\hline 29 boreal reservoirs & Canada & FC & 1993 to 2003 & $3.37(-5.57-10.34)$ & [25] \\
\hline Lokka & Finland & $\mathrm{FC}$ & Jun. to Sep., 1994, 1995 & $-3.52-11.44$ & [26] \\
\hline Porttipahta & Finland & FC & Jun. to Sep., 1994, 1995 & $-0.88-10.56$ & {$[26]$} \\
\hline ELA in Ontario & Canada & BLM & $2000-2001$ & $-0.15--0.042$ & [27] \\
\hline
\end{tabular}

*Note: FC: Floating Chambers; BLM: Boundary Layer Method

\section{Discussion}

\section{Seasonal Variability of $\mathrm{N}_{2} \mathrm{O}$ Emission}

The average $\mathrm{N}_{2} \mathrm{O}$ emission flux in the surfaces of Xin'anjiang Reservoir was $34.84 \mu \mathrm{g} \mathrm{m}^{-2} \cdot \mathrm{s}^{-1}$, which was lower than those in 3 Amazonian tropical reservoirs, comparable to those from subtropical and temporal reservoirs, but higher than those at the boreal reservoirs (Table 1). The geographic location of reservoirs is an important factor influencing $\mathrm{N}_{2} \mathrm{O}$ emission flux because of the differences in temperature.

The maximal values of $\mathrm{N}_{2} \mathrm{O}$ emission from the $\mathrm{NW}$, NE, SW, and SE occurred in March simultaneously (Figs 2,3), which presumably was related with the vertical mixing of the water column then [13]. An explanation was that the highest level of $\mathrm{N}_{2} \mathrm{O}$ emission during the turnover periods derived from new $\mathrm{N}_{2} \mathrm{O}$ production resulting from the nitrification of $\mathrm{NH}_{4}^{+}$ released from the hypolimnion. Lacking direct support by relevant $\mathrm{N}_{2} \mathrm{O}$ data in this study, but elevated $\mathrm{N}_{2} \mathrm{O}$ emission associated with nitrification during lake turnover periods have been reported in East Fork Lake Reservoir, Ohio, USA and Wujiangdu Reservoir, Guizhou, China [7, 11]. The dissolved $\mathrm{N}_{2} \mathrm{O}$ saturation ratio increased significantly from prior to turnover periods to turnover periods, with supersaturation in the epilimnion, causing a strong concentration gradient between the atmosphere and water surface, and a high level of $\mathrm{N}_{2} \mathrm{O}$ emission subsequently occurred in the airwater interface [7, 11].

The peak of $\mathrm{N}_{2} \mathrm{O}$ emission from the downstream river was different from the other locations, with the maximum in December 2014 to January 2015 (Fig. 3), which was probably induced by the interference of the water discharge and the variation of dissolved $\mathrm{N}_{2} \mathrm{O}$ concentration before the dam. Water discharge rate decreased from December 2014 to February 2015, and reached the minimum at February (Fig. 5). The variability of dissolved $\mathrm{N}_{2} \mathrm{O}$ concentrations before the dam was likely an important indicator for the seasonal $\mathrm{N}_{2} \mathrm{O}$ emission from the downstream river. Unfortunately, the dissolved $\mathrm{N}_{2} \mathrm{O}$ concentrations were not measured during our experiments.

\section{Spatial Variability of $\mathrm{N}_{2} \mathrm{O}$ Emission}

A significantly high $\mathrm{N}_{2} \mathrm{O}$ emission flux was observed in the downstream river (Fig. 4), which was about 3-7 times higher than the average $\mathrm{N}_{2} \mathrm{O}$ fluxes in the 4 transects before the dam. Similarly, $\mathrm{N}_{2} \mathrm{O}$ emissions from the downstream rivers of the 2 tropical reservoirs 


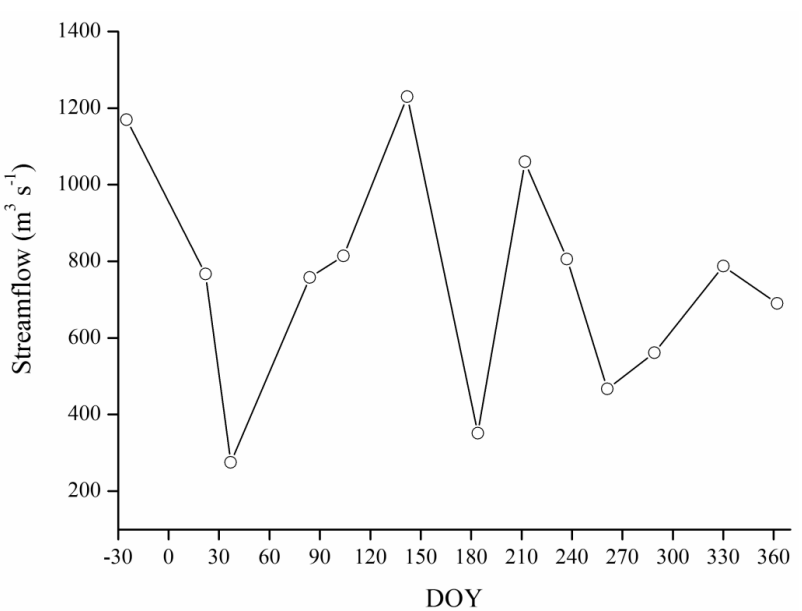

Fig. 5. Discharge flow at the outlet of Xin'anjiang Dam at 9 a.m.

(Petit Saut, Fortuna) and 3 subtropical reservoirs (Yinzidu, Suofengying, Wujiangdu) were significantly higher than those from water surfaces before the dam $[19,28]$.

The obviously increased $\mathrm{N}_{2} \mathrm{O}$ emitted from the downstream river might have the following origins: (1) the $\mathrm{N}_{2} \mathrm{O}$ produced in the hypolimnion water column before the dam that passed through the turbines but did not degas completely at the dam, because high solubility of $\mathrm{N}_{2} \mathrm{O}$ (1: $1.5 \mathrm{vol} . / \mathrm{vol}$. dissolved in water at $20^{\circ} \mathrm{C}$ and standard atmospheric pressure) would keep plenty of dissolved $\mathrm{N}_{2} \mathrm{O}$ concentrations in the river waters, which was oversaturation compared with the nearby atmosphere in the downstream river; (2) in situ production in the river, by denitrification in the sediments and/or nitrification in the water column or surface sediments [19, 28].

The high $\mathrm{N}_{2} \mathrm{O}$ emission from the downstream river was probably overestimated during our measurement periods. Because of the fast water discharge below the dam, the fast water current velocity made our sampling work hard, so the anchored flux chambers were used to collect gas samples. Actually, such methods have been proven to overestimate greenhouse gas emissions compared with the drift chambers because of the elevated turbulence [29].

\section{Conclusions}

$\mathrm{N}_{2} \mathrm{O}$ emission from Xin'anjiang Reservoir has spatiotemporal variability, with a high emission level in March and the downstream river. A long-term monitoring campaign that covers the different locations of the reservoir should be carried out to estimate the total $\mathrm{N}_{2} \mathrm{O}$ emission from reservoir previously. The mechanism of nitrification and denitrification in the water column should be further studied to reveal the reasons for $\mathrm{N}_{2} \mathrm{O}$ emission variability in the space and temporal scales.

\section{Acknowledgements}

The study was funded by the National Natural Science Foundation of China (41303065) and Zhejiang Hangzhou Urban Forest Ecosystem Research Station. We thank the Xin'anjiang hydropower plant for provision of streamflow data below the dam (Fig. 5), Sun Binfeng for the photograph in Fig. 1.

\section{Conflict of Interest}

The authors declare no conflict of interest.

\section{References}

1. LI B.G., GASSER T., CIAIS P., PIAO S.L., TAO S., BALKANSKI Y., HAUGLUSTAINE D., BOISIER J.P., CHEN Z., HUANG M., Li L.Z., LI Y., LIU H.Y., PENG S.S., SHEN Z.H., SUN Z.Z., WANG R., WANG T., YIN G.D., YIN Y., ZENG H., ZENG Z.Z., ZHOU F. The contribution of China's emissions to global climate forcing. Nature, 531, 357, 2016.

2. KÖHLER P., NEHRBASS-AHLES C., SCHMITT J., STOCKER T.F., FISHCHER H. A $156 \mathrm{kyr}$ smoothed history of the atmospheric greenhouse gases $\mathrm{CO}_{2}, \mathrm{CH}_{4}$, and $\mathrm{N}_{2} \mathrm{O}$ and their radiative forcing. Earth System Science Data, 9 (1), 363, 2017.

3. LEHNER B. High-resolution mapping of the world's reservoirs and dams for sustanable river-flow management. Frontiers in Ecology and the Environment, 15, 494, 2011.

4. DEEMER B.R., HARRISON J.A., LI S.Y., BEAULIEU J.J., DELSONTRO T., BARROS N., BEZERRA-NETO J.F., POWERS S.M., DOS SANTOS M.A., ARIE VONK J. Greenhouse gas emissions from reservoir water surfaces: a new global synthesis. BioScience, 66 (11), 949, 2016.

5. HU M.P., CHEN D.J., DAHLGREN R.A. Modeling nitrous oxide emission from rivers: a global assessment. Global Change Biology, 22, 3566, 2016.

6. MURRAY R.H., ERLER D.V., EYRE B.D. Nitrous oxide fluxes in estuarine environments: response to global warming. Global Change Biology, 21, 3219, 2015.

7. LIU X.L., LIU C.Q., LI S.L., WANG F.S., WANG B.L., WANG Z.L. Spatiotemporal variations of nitrous oxide $\left(\mathrm{N}_{2} \mathrm{O}\right)$ emissions from two reservoirs in SW China. Atmospheric Environment, 45, 5458, 2011.

8. LIU X.L., LI S.L., WANG Z.L., HAN G.L., LI J., WANG B.L., WANG F.S., LI B. Nitrous oxide $\left(\mathrm{N}_{2} \mathrm{O}\right)$ emissions from a mesotrophic reservoir on the Wujiang River, southwest China. Acta Geochimica, 36 (4), 1, 2017.

9. ZHU D., CHEN H., YUAN X.Z., WU N., GAO Y.H., WU Y., ZHANG Y.M., PENG C.H., ZHU Q.A., YANG G., WU J.H. Nitrous oxide emissions from the surface of the Three Gorges Reservoir. Ecology Engineering, 60, 150, 2013.

10. ZHAO Y., WU B.F., ZENG Y. Spatial and temporal patterns of greenhouse gas emissions from Three Gorges Reservoir of China. Biogeosciences, 10, 1219, 2013.

11. BEAULIEU J.J., NIETCH C.T., YOUNG J.L. Controls on nitrous oxide production and consumption in reservoirs of the Ohio River basin. Journal of Geophysical Research: Biogeosciences, 120, 1995, 2015.

12. WANG J., CHEN N.W., YAN W.J., WANG B., YANG L.B. Effect of dissolved oxygen and nitrogen on emission 
of $\mathrm{N}_{2} \mathrm{O}$ from rivers in China. Atmospheric Environment, 103, 347, 2015.

13. ZHANG Y.L., WU Z.X., LIU M.L., HE J.B., SHI K., WANG M.Z., YU Z.M. Thermal structure and response to long-term climatic changes in Lake Qiandaohu, a deep subtropical reservoir in China. Limnology and Oceanograph, 59 (4), 11932, 2014.

14. ZHANG Y.L., WU Z.X., LIU M.L., HE J.B., SHI K., ZHOU Y.Q., WANG M.Z., LIU X.H. Dissolved oxygen stratification and response to thermal structure and longterm climate change in a large and deep subtropical reservoir (Lake Qiandaohu, China). Water Research, 75, 249, 2015.

15. WANG F.S., CAO M., WANG B.L., FU J.N., LUO W.Y., MA J. Seasonal variation of $\mathrm{CO}_{2}$ diffusion flux from a large subtropical reservoir in East China. Atmospheric Environment, 103, 129, 2015.

16. YU Y.L., REN L.P., LIU Q.G., SHI W., LIU G.D., HE G.X., CHEN L.S., HONG R.H. Temporal and spatial distribution of nutrients and influencing factors of Lake Qiandao during 2007-2008. Journal of Lake Sciences, 22 (5), 684, 2010.

17. LI P.P., SHI W., LIU Q.G., YU Y.L., HE G.X., CHEN L.S., REN L.P., HONG R.H. Spatial and temporal distribution patterns of chlorophyll-a and the correlation analysis with environmental factors in Lake Qiandao. Journal of Lake Science, 23 (4), 568, 2011.

18. HUTCHINSON G., LIVINGSTON G., Vents and seals in non-steady-state chambers used for measuring gas exchange between soil and atmosphere, European Journal of Soil Science, 52, 675, 2001.

19. GUÉRIN F., ABRIL G., TREMBLAY A., DELMAS R. Nitrous oxide emissions from tropical hydroelectric reservoirs. Geophysical Research Letter, 35, L06404, 2008.

20. LIMA I.B.T., VICTORIA R.L., NOVO E.M.L., FEIGL B.J., BALLESTER M.V.R., OMETTO J.P. Methane, carbon dioxide and nitrous oxide emissions from two Amazonian Reservoirs during high water table. Verhandlungen des Internationalen Verein Limnologie, 28, 438, 2002.

21. DESCLOUX S., CHANUDET V., SERÇA D., GUÉRIN F. Methane and nitrous oxide annual emissions from an old eutrophic temperate reservoir. Science of the Total Environment, 598, 959, 2017.
22. BEAULIEU J.J., SMOLENSKI R.L., NIETCH C.T., TOWNSEND-SMALL A., ELOVITZ M.S., SCHUBAUER-BERIGAN J.P. Denitrification alternates between a source and sink of nitrous oxide in the hypolimnion of a thermally stratified reservoir. Limnology and Oceanography, 59 (2), 495, 2014.

23. JACINTHE P.A., FILIPPELLI G.M., TEDESCO L.P., RAFTIS R. Carbon storage and greenhouse gases emission from a fluvial reservoir in an agriculture landscape. Catena, 94, 53, 2012.

24. LI H.L., YANG M., ZHANG M.X., LEI T., LEI G.C. Characteristics and environmental determines of greenhouse gas emissions from Yudushan Reservoir during growth season. Chinese Journal of Ecology, 31 (2), 406, 2012.

25. TREMBLAY A., THERRIEN J., HAMLIN B., WICHMANN E., LEDREW L.J. GHG emissions from boreal reservoirs and natural aquatic ecosystems. In Greenhouse gas emissions-fluxes and processes: hydroelectric reservoirs and natural environments $1^{\text {st }}$ ed.; TREMBLAY A., VARFALVY L., ROEHM C., GARNEAU M., Eds., Springer, New York, USA, 209, 2005.

26. HUTTUNEN J.T., VÄISÄNEN T.S., HELLSEN S.K., HEIKKINEN M., NYKÄNEN H., JUNGNER H., NISKANEN A., VIRTANEN M.O., LINDQVIST O.V., NENONEN O.S., MARTIKAINEN P.J. Fluxes of $\mathrm{CH}_{4}$, $\mathrm{CO}_{2}$, and $\mathrm{N}_{2} \mathrm{O}$ in hydroelectric reservoirs Lokka and Porttipahta in the northern boreal zone in Finland. Global Biogeochemistry Cycles, 16 (1), 1, 2002.

27. HENDZEL L.L., MATTHEW C.J.D., VENKITESWARAN J.J., ST. LOUIS V.L., BURTON D., JOYCE E.M., BODALY R.A. Nitrous oxide fluxes in three experimental boreal forest reservoirs. Environmental Science \& Technology, 39, 4353, 2005.

28. LIU X.L., WANG F.S., BAI L., LI S.L., WANG B.L., LIU C.Q., WANG Z.L. Impact of cascade reservoir development on $\mathrm{N}_{2} \mathrm{O}$ emission in the Wujiang River. Journal of Shanghai University (Natural Science), 21 (3), 301, 2015.

29. LORKE A., BODMER P., NOSS C., ALSHBOUL Z., KOSCHORRECK M. Technical note: drifting versus anchored flux chambers for measuring greenhouse gas emissions from running waters. Biogeosciences, 12 (23), 7013, 2015 